\title{
The Savory Method Can Not Green Deserts or Reverse Climate Change
}

\section{A response to the Allan Savory TED video}

\author{
By David D. Briske, Brandon T. Bestelmeyer, Joel R. Brown, Samuel D. Fuhlendorf, \\ and H. Wayne Polley
}

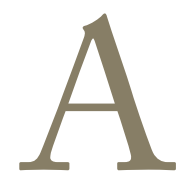

llan Savory stated that his "planned grazing" method was necessary to reverse two of the world's most challenging and interlinked global change processes-desertification and climate change - in the video "How to green the world's deserts and reverse climate change" that was presented in session 7 at the 2013 TED (Technology, Entertainment, Design) Conference on 27 February 2013 in Long Beach, California. ${ }^{i}$ As members of the scientific community, it is our obligation to evaluate the claims made in this video relative to the existing scientific information on this topic.

We find all of Mr Savory's major claims to be unfounded and we express deep concern that they have the potential to undermine proven, practical approaches to rangeland management and restoration that are supported by a global community of practitioners and scientists. The two major assumptions underlying $\mathrm{Mr}$ Savory's presentation are alone sufficient grounds for extreme skepticism. First is that humans have misunderstood the basic grassland-grazer relationships for centuries and that only he knows the true nature of this relationship. Second is that use of intensive, concentrated livestock grazing, specific to the method that $\mathrm{Mr}$ Savory developed, is the only viable solution to reverse desertification and climate change. In addition to challenging these two highly problematic assumptions, we present a specific critique of three invalid arguments that Mr Savory used to claim that his grazing method can reverse desertification, climate change, and alleviate human suffering and death (19:00 in video).

\section{Invalid Argument 1: All Nonforested Lands Are Degraded}

Mr Savory claims that all nonforested land on the planet is degrading and that the reasons for degradation are not understood (2:40 and 7:16 in video). This is absolutely false

A video of the talk is available online at: http://www.ted.com/talks/ allan_savory_how_to_green_the_world_s_deserts_and_reverse_ climate_change.html in both respects because many rangelands are well managed and deserts are a consequence of climate and soil factors, in addition to inappropriate management. He justified this claim by discrediting rangeland science as indicated in his statement that "a century of rangeland management has increased land degradation." Global rangeland degradation represents a serious concern, but it is often a consequence of increasing human and livestock populations, land fragmentation, changes to land tenure, and poverty, rather than invalid or insufficient scientific information. ${ }^{1}$ The pressing challenge is to develop broad approaches that can be implemented at multiple levels of social organization to minimize these pervasive and complex issues confronting rangeland sustainability. The tactic of discrediting science detracts from progress toward this goal, because it continues to oversimplify the complexity of rangeland systems and to promote narrowly focused technological solutions. ${ }^{2} \mathrm{How}^{-}$ ever, this ploy is the only alternative available to Mr Savory because his claims are not only unsupported by scientific information, but they are often in direct conflict with it. ${ }^{3}$

\section{Invalid Argument 2: Rangelands Can Store All Fossil Fuel Carbon in the Atmosphere}

Mr Savory's claim that his grazing method can reduce atmospheric carbon (C) concentrations to preindustrial levels (a 30\% reduction; 400 vs. 280 ppm $\mathrm{CO}_{2}$ ) (19:30 in video) is an enormous misrepresentation of the global carbon cycle and climate change science. Fossil fuel combustion, followed distantly by deforestation, land conversion, and degradation are the major contributors to increasing atmospheric $\mathrm{C}$ and global warming. Consequently, strategies to offset climate change by increasing $\mathrm{C}$ storage in soils and vegetation, described as $\mathrm{C}$ sequestration, are extremely limited relative to the current rate of global $\mathrm{C}$ emissions. Rangelands are known to be very weak sinks for atmospheric $\mathrm{C}$ because plant production is water limited and more $\mathrm{C}$ is often released into the atmosphere from soil respiration than is take up by vegetation, especially during drought periods. ${ }^{4}$ 
We present a few key values from the global $\mathrm{C}$ cycle to identify the inaccuracy of Mr Savory's claims regarding the potential for his grazing method, or any grazing method, to sequester C. In 2012, global greenhouse gas emissions were estimated at about 50 billion metric tons $\left(\mathrm{CO}_{2}\right.$ equivalents; $\left.\mathrm{CO}_{2} \mathrm{e}\right) .{ }^{1}$ In order to offset these current emissions, rangelands would have to sequester approximately 13.6 billion tons of $\mathrm{C}$ annually. ${ }^{\text {ii }}$ Given that there are about five billion hectares of rangeland globally, it is relatively simple to calculate that each hectare of rangeland would have to sequester an additional two tons of $\mathrm{C}$ each year. Credible estimates of the potential for rangeland $\mathrm{C}$ sequestration are generally less than 0.25 tons $\mathrm{C}$ per hectare per year, which is eight-fold less than $\mathrm{Mr}$ Savory's claims would require.

Even this estimate of the large discrepancy in rangeland $\mathrm{C}$ sequestration is extremely conservative because of the inherent ecological limitations that control plant production and $\mathrm{C}$ sequestration. Grass biomass is about $40 \% \mathrm{C}$, so that sequestering 2.5 tons of $\mathrm{C}$ per hectare would require that approximately 6.25 tons per hectare $(6,250 \mathrm{~kg}$ or $12,500 \mathrm{lbs})$ of dry matter be produced each year. Given that the vast majority of the world's rangelands are arid and semiarid, the opportunities for achieving these levels of plant production are all but impossible. ${ }^{5}$ In addition, only a portion of the $\mathrm{C}$ in plant biomass production is stored in the soil as organic $\mathrm{C}$, while the majority is released back into the atmosphere as $\mathrm{CO}_{2}$ from plant and soil microbial respiration (a cellular biochemical process that releases carbon dioxide during energy production, it is driven largely by temperature and soil water availability $^{6}$ ).

Finally, the capacities of soils to sequester $\mathrm{C}$ do not increase indefinitely, but they encounter upper limits set by climate, vegetation, and soil characteristics. Most estimates set the $\mathrm{C}$ sequestration potential of global rangelands between one and two billion tons per year, a significant amount to be sure, but hardly sufficient to offset current $\mathrm{C}$ emissions (50 billion tons in 2012). In addition, rain-fed rangelands are estimated to attain new upper limits on $\mathrm{C}$ sequestration in about two decades following major improvements in management strategies. Consequently, currently recommended rangeland management strategies place greater emphasis on the conservation of existing soil $\mathrm{C}$, rather than the sequestration of additional $\mathrm{C}$.

\section{Invalid Argument 3: Intensive Grazing is Necessary to Prevent Rangeland Degradation} The ecological benefits of concentrated livestock grazing or "hoof action" to rangeland restoration and $\mathrm{C}$ sequestration are grossly overstated and without supporting evidence, other than for a few select photos. ${ }^{3}$ Two of the photos presented in

\footnotetext{
"The atomic weight of $\mathrm{CO} 2$ is 44 : carbon $=12$, oxygen $=16$. Therefore $\mathrm{CO} 2=12+16+16=44$. For our purposes, 13.6 billion tons of $\mathrm{C}$ must be stored in the soil to offset 50 billion tons of atmospheric CO2 (50 $\times 0.27$.
}

the video were misrepresented. One, occurring within Chaco Culture National Historical Park, was identified in a web comment on the TED talk by Bernard Foy (8 March 2013) as an area that is slowly recovering from a historical period of mismanaged grazing, rather than as a consequence of grazing exclusion as indicated by $\mathrm{Mr}$ Savory. Another set of repeat photographs, assembled by one of the authors (Bestelmeyer), were inappropriately associated with Jornada Experimental Range, but were actually of a small patch of desert grassland within the Las Cruces International Airport in southwestern New Mexico (toward the top of the "X" runways, which can be found in Google Earth).

We briefly describe this misrepresentation of the desert grassland example in southern New Mexico to disprove $\mathrm{Mr}$ Savory's claim that nonuse by livestock contributes to rangeland degradation. This area has been, as Mr Savory indicates, ungrazed by domestic livestock since the 1950s and there had been an obvious decline in grass cover in spite of grazing exclusion (as of 2003). Wind erosion of sandy soils in the surrounding desertified landscape was proposed as a cause for this decline, rather than grazing exclusion. ${ }^{8}$ Wind moves large amounts of sand that are deposited on and trigger erosion around remnant plants, causing mortality and limiting reproduction, even in the absence of grazing. This grass patch is a relict within a desertifying landscape that only exists at all because it was fenced.

The pertinent question in this case, however, is: could $\mathrm{Mr}$ Savory's grazing method have prevented or now restore this remnant grassland patch? We have tested the effects of intensive grazing and rest from grazing on the dominant grass, black grama (Bouteloua eriopoda), in this desert grassland. ${ }^{9}$ Grass cover increases dramatically with rest and intensive grazing delays this recovery. Most relevant to Mr Savory's claims, we found no evidence that grass cover had declined with 13 years of rest in a noneroding landscape. Erosion and drought can act suddenly in desert grasslands of the southwestern United States to produce widespread mortality of the dominant perennial grass black grama. ${ }^{10}$ Fortunately, livestock producers of the region recognize that flexible grazing management is needed to sustain these arid grasslands.

It is also useful to consider the proposed mechanisms by which grazing should benefit perennial grasses like black grama. Many of the soils in this desert grassland are sandy and crusting does not limit infiltration, so the mechanical action of hooves does not increase infiltration. In contrast, the biological crusts implicated as a contributor to desertification by $\mathrm{Mr}$ Savory are known to stabilize the sandy soil surface and protect it from wind erosion and carbon loss. ${ }^{11,12}$ Similarly, experimental data from Botswana confirm the importance of soil biological crusts for cycling rangeland $\mathrm{C}$ and specifically indicate that intensive grazing, which destroys these crusts through trampling and burial, will adversely affect $\mathrm{C}$ sequestration and storage. ${ }^{13}$ This research concluded that managed grazing, where soil surfaces are only lightly disturbed, would help maintain a positive $\mathrm{C}$ balance in African rangelands. 


\section{Our Final Take}

Progress regarding rangeland management is being made in many portions of the globe, but there are significant environmental, social, and political challenges to overcome, including human population growth, climate change, poverty, war, and inadequate education. Mr Savory's attempts to divide science and management perspectives and his aggressive promotion of a narrowly focused and widely challenged grazing method only serve to weaken global efforts to promote rangeland restoration and $\mathrm{C}$ sequestration. The false sense of hope created by his promises, expressly regarding some of the most desperate communities, are especially troubling. Scientific evidence unmistakably demonstrates the inability of $\mathrm{Mr}$ Savory's grazing method to reverse rangeland degradation or climate change, and it strongly suggests that it might actually accelerate these processes.

\section{References}

1. United Nations Environment Program. 2012. Greenhouse gas emissions gap widening as nations head to crucial climate talks in Doha. Available at: http://www.unep.org/newscentre/ default.aspx?DocumentID=2698\&ArticleID=9335. Accessed 24 June 2013.

2. Briske, D. D., N. F. Sayre, L. Huntsinger, M. FernandezGimenez, B. Budd, and J. D. Derner. 2011. Origin, persistence, and resolution of the rotational grazing debate: integrating human dimensions into rangeland research. Rangeland Ecology \& Management 64:325-334.

3. Briske, D. D., J. D. Derner, J. R. Brown, S. D. Fuhlendorf, W. R. Teague, K. M. Havstad, R. L. Gillen, A. J. Ash, and W. D. Willms. 2008. Rotational grazing on rangelands: reconciliation of perception and experimental evidence. Rangeland Ecology Eं Management 61:3-17.

4. Svejcar, T., R. Angell, J. A. Bradford, W. Dugas, W. Emmerich, A. B. Frank, T. Gilmanov, M. Haferkamp, D. A. Johnson, H. Mayeux, P. Mielnick, J. Morgan, N. Z. Saliendra, G. E. Schuman, P. L. Sims, and K. Snyder. 2008. Carbon fluxes on North American rangelands. Rangeland Ecology \& Management 61:465-474.

5. Yang, Y., J. FAng, W. Ma, And W. Wang. 2008. Relationship between variability in aboveground net primary production and precipitation in global grasslands. Geophysical Research Letters 35:L23710.

6. Huxman, T. E., K. A. Knyder, D. Tissue, A. J. Leffler, K. Ogle, W. T. Pockman, D. R. Sandeuist, D. L. Potts, and S. Schwinning. 2004. Precipitation pulses and carbon fluxes in semiarid and arid ecosystems. Oecologia 141:254-268.
7. Booker, K., L. Huntsinger, J. W. Bartolome, N. F. Sayre, and W. Stewart. 2013. What can ecological science tell us about opportunities for carbon sequestration on arid rangelands in the United State? Global Environmental Change 23:240-251.

8. Bestelmeyer, B. T., D. A. Trujillo, A. J. Tugel, and K. M. Havstad. 2006. A multi-scale classification of vegetation dynamics in arid lands: What is the right scale for models, monitoring, and restoration? Journal of Arid Environments 65:296318.

9. Bestelmeyer, B. T., M. C. Duniway, D. K. James, L. M. BurKett, And K. M. Havstad. 2013. A test of critical thresholds and their indicators in a desertification-prone ecosystem: more resilience than we thought. Ecology Letters 16:339-345.

10. Bestelmeyer, B. T., A. M. Ellison, W. R. Fraser, K. B. Gorman, S. J. Holbrook, C. M. Laney, M. D. Ohman, D. P. C. Peters, F. C. Pillsbury, A. Rassweiler, R. J. Schmitt, and S. Sharma. 2011. Analysis of abrupt transitions in ecological systems. Ecosphere 2:art129.

11. Marticorena, B., G. Bergametti, D. Gillette, and J. BeLnAP. 1997. Factors controlling threshold friction velocity in semiarid and arid areas of the United States. Journal of Geophysical Research: Atmospheres 102:23277-23287.

12. Barger, N. N., J. E. Herrick, J. Van Zee, and J. Belnap. 2006. Impacts of biological soil crust disturbance and composition on $\mathrm{C}$ and N loss from water erosion. Biogeochemistry 77:247-263.

13. Thомаs, A. D. 2012. Impact of grazing intensity on seasonal variations in soil organic carbon and soil $\mathrm{CO}_{2}$ efflux in two semiarid grasslands in southern Botswana. Philosophical Transactions of the Royal Society B. 367:3076-3086.

Authors are Professor, Dept of Ecosystem Science and Management, Texas AE'M University, College Station, TX 77843, USA, dbriske@tamu.edu (Briske); Research Ecologist, USDAARS, Jornada Experimental Range and Jornada Basin LTER, New Mexico State University, Las Cruces, NM 88003, USA (Bestelmeyer); Research Scientist, USDA-NRCS, Jornada Experimental Range, Las Cruces, NM 88003 (Brown); Starkey's Distinguished Professor, Dept of Natural Resources Ecology E Management, Oklahoma State University, Stillwater, OK 74077, USA (Fublendorf); Research Ecologist, USDA-ARS, Grassland, Soil Eo Water Research Laboratory, Temple, TX 76502, USA (Polley).

Rangelands 35(5):72-74

doi: 10.2111/RANGELANDS-D-13-00044.1

(C) 2013 The Society for Range Management 